\title{
Fatty acid analysis of subcutaneous fat from animals with a reliable and safe feeding
}

\author{
By C. Sanabriaa ${ }^{a}$, , M.J. Martín-Mateos ${ }^{a}$, N. González-Cantilloa, I. Moreno-Indias ${ }^{a}$ \\ and J.M. García-Casco ${ }^{\mathrm{b}}$
}

\author{
${ }^{a}$ Instituto Tecnológico Agroalimentario de Extremadura, Gobierno de Extremadura, 06071 Badajoz, Spain \\ ${ }^{\text {b }}$ Centro de I+D en Cerdo Ibérico-INIA, 06300 Zafra, Spain \\ * Corresponding author: carmela.sanabria@juntaextremadura.es
}

\section{RESUMEN}

Análisis de ácidos grasos en grasa subcutánea procedentes de animales de alimentación fiable y segura

Las características de la grasa de cerdo Ibérico dependen del tipo de alimentación recibida en el último estadío de engorde. El análisis que se ha utilizado hasta ahora para diferenciar las diferentes calidades de alimentación de los cerdos en este período ha sido el análisis de los perfiles de ácidos grasos de la grasa por técnicas de cromatografía de gases. Debido a las dudas sobre la efectividad de esta técnica en la montanera, el objetivo del proyecto global (RTA2008-0026) fue probar la validez de varios métodos analíticos para determinar el tipo de alimentación del cerdo ibérico, centrándonos en este trabajo en el estudio de los perfiles de ácidos grasos. Para el desarrollo de este estudio se utilizaron tres campañas de montanera con un total de 749 muestras de 38 partidas, y con 144 paletas de las cuales 99 tenían una trazabilidad completa. Los resultados mostraron que la determinación de la alimentación de los cerdos ibéricos usando el análisis del perfil de ácidos grasos no es un método consistente para clasificar los animales de acuerdo a la categoría de recebo, mientras que para las categorías de bellota y cebo, los resultados encontrados mostraron unos buenos porcentajes de éxito.

PALABRAS CLAVE: Cerdo Ibérico - Montanera - Paleta ibérica - Perfil de ácidos grasos.

\section{SUMMARY}

Fatty acid analysis of subcutaneous fat from animals with a reliable and safe feeding

Iberian pig fat characteristics depend on the type of feeding at the end of its finish-fattening period. The routine analysis to differentiate among the qualities of the feeding types given to the pigs in the fattening stage has been the use of fatty acid profiles by gas chromatography. Due to de doubts about the effectiveness of this analysis in the montanera period, the aim of this global study was to test the validity of various analytical methods to determine the feeding type of Iberian pigs, focusing on the fatty acid profile. Three montanera periods with a total of 749 samples from 38 batches have been studied; using a total of 144 dry-cured shoulder shanks, 99 of which are of known pig origin. Results showed that the determination of the fatty acid profile using gas chromatography is not a consistent method to classify the animals according to diet in the recebo category, although it provided good percentages of success for classifying the bellota and cebo categories.

KEY-WORDS: Dry-cured shoulder - Fatty acid profile Iberian pig - Montanera.

\section{INTRODUCTION}

Diet is one of the main factors likely to modify the composition of animal tissues, mainly in monogastric animals such as the pig, and considerably conditions the final characteristics of its carcass and products (García-Olmo et al., 2002). Nowadays, it is known that lberian pig fat characteristics depend on the type of feeding at the end of its finish-fattening period, and that the use of different types of diets, based on acorns or feed concentrates, has a significant repercussion on the fatty acid profile of the adipose tissues of its carcass (Ruíz et al., 1998).

The Designation of Origin committees for Iberian pig products, the Interprofessional Association of the Iberian Pig (ASICl) and the sector's industries, have used the analysis of the fatty acids profile by gas chromatography as a criterion to differentiate among the qualities of the feeding types given to the pigs in the fattening stage (García-Olmo et al., 2002). This method has been used since 2001, when the MAPA (Ministerio de Agricultura, Pesca y Alimentación) published the Real Decreto 1083/2001 (B.O.E. 247, 2001) which established the dry-cured ham, shoulder and loin elaborated according to the Spanish Quality Standards. In this standard the fatty acid analysis of the subcutaneous fat deposit was established as a complementary method to field inspections in order to label the products according to the pigs' diets in their finishfattening period. This method was official with the publication of the Real Decreto 1781/2004 (B.O.E. $211,2004)$, which modifies the Quality Standard. However, animal feed industries have developed formulas with a fatty acid profile similar to the official profile established for the classification of the animals in the category of bellota, without the necessity that the animals have been in the dehesa: these are the called false positives. Moreover, it also finds false negatives for Iberian pigs that have been fed only with acorns and classified them into the recebo category. Some Designations of Origin, in which field visits have a huge importance, decided not to use this method; others decided to apply it in a strict way. To sum up, a generalized controversy exists about the use of the fatty acid profile to distinguish among diets. 
Due to the doubts about the effectiveness of this analysis to determine the feeding received by the pigs in the montanera stage, it was proposed to the MARM (Ministerio de Agricultura, Alimentación y Medio Ambiente) and INIA (Instituto Nacional de Investigaciones Agrarias) that a three-year-long project be undertaken which was accepted in 2008 (ref. RTA2008-0026) with the tittle: "Evaluation of the feeding received by Iberian Pigs in the final cebo stage using different instrumental techniques and analysis. Applicability and reliability"

The aim of this study was to test the validity of various analytical methods to determine the feeding type of Iberian Pigs (García-Casco et al., 2013), provided by the meat products area of INTAEX (Instituto Tecnológico Agroalimentario de Extremadura, from Junta de Extremadura) using the traditional analytic method: the fatty acid profile or analysis of the fatty acids.

\section{MATERIAL AND METHODS}

Subcutaneous fat from Iberian pigs of three montanera periods (2008/09, 2009/10 and 2010/11), in which the four feeding categories (bellota, recebo, campo y cebo) of the Quality Standard were represented, were analyzed (B.O.E. 264, (2007)). Samples were provided by the Cerdo Ibérico Center (INIA, Zafra), where organization and coordination of the project, animal control, sampling, and interpretation of results were done. Moreover, an analysis of the cover fat from the drycured shoulders of the two first periods used as control batches was carried out.

For the whole study, a total of 749 samples from 38 batches were analyzed (Table 1), a detailed description of each pig batch can be found in García-Casco et al. (2013). In table 2, the number of dry-cured shoulders analyzed is shown, along with their origin according to the feedings, with a total of 144 dry-cured shoulders, 99 of which with their pig origin known.

The procedure for the fatty acid profile determination was as follows: skin and lean parts were removed from the subcutaneous adipose tissue

Table 1

Number of subcutaneous fat deposit samples analyzed according to each of the controlled batches in the periods 08/09, 09/10 y 10/11

\begin{tabular}{lrrrr}
\hline & \multicolumn{3}{c}{ Periods } & Total \\
\cline { 2 - 4 } & $\mathbf{0 8 / 0 9}$ & $\mathbf{0 9 / 1 0}$ & $\mathbf{1 0 / 1 1}$ & \\
\hline Batches & 8 & 8 & 22 & 38 \\
Bellota & 61 & 55 & 135 & 251 \\
Recebo & 40 & 50 & 74 & 164 \\
Campo & 75 & 75 & 47 & 197 \\
Cebo & 32 & 25 & 80 & 137 \\
Total & $\mathbf{2 0 8}$ & $\mathbf{2 0 5}$ & $\mathbf{3 3 6}$ & $\mathbf{7 4 9}$ \\
\hline
\end{tabular}

Table 2

Number of dry-cured shoulders $(\mathrm{N})$ of the periods $08 / 09$ y $09 / 10$ on which the cover fat analysis was done and the number of dry-cured shoulders with traceability $\left(\mathbf{N}^{\mathrm{tr}}\right)$ from the animal origin to the drycured shoulder

\begin{tabular}{|c|c|c|c|c|c|c|}
\hline & \multicolumn{4}{|c|}{ Periods } & \multirow{2}{*}{\multicolumn{2}{|c|}{ Total }} \\
\hline & \multicolumn{2}{|c|}{$08 / 09$} & \multicolumn{2}{|c|}{$09 / 10$} & & \\
\hline & $N$ & $\mathbf{N}^{\text {tr }}$ & $N$ & $\mathrm{~N}^{\mathrm{tr}}$ & $N$ & $\mathbf{N}^{\text {tr }}$ \\
\hline Bellota & 20 & 10 & 18 & 10 & 38 & 20 \\
\hline Recebo & 10 & 10 & 20 & 20 & 30 & 30 \\
\hline Campo & 27 & 20 & 29 & 19 & 56 & 39 \\
\hline Cebo & 10 & 10 & 10 & & 20 & 10 \\
\hline Total & 67 & 50 & 77 & 49 & 144 & 99 \\
\hline
\end{tabular}

samples, and then chopped and homogenized. Total lipids were obtained by fusion in a microwave oven (B.O.E. 283, 2004). Methyl esters were prepared by the addition of $\mathrm{KOH}$ and methanol, according to the Order PRE/3844/2004 (B.O.E. $283,2004)$. The composition of the 12 fatty acids established by the Order PRE/3844/2004 (B.O.E. 283,2004 ), was carried out on a gas chromatograph (Hewlett Packard Agilent, model 6890N, Hewlett Packard, Santa Clara, CA), equipped with a flame ionizer detector (FID). Methyl esters were separated by a silica capillary column (OMEGAWAX 320 , Sigma-Aldrich, St. Louis, MO), according to UNEEN ISO 5508:1996. The injector temperature was maintained at $230^{\circ} \mathrm{C}$ and the detector at $300^{\circ} \mathrm{C}$, while the oven was programmed with a gradient temperature between 185 and $220^{\circ} \mathrm{C}$. The carrier gas was hexane, with a flux of $1.2 \mathrm{~mL} \mathrm{~min}^{-1}$. Fatty acid identification was done by the comparison of the retention times with the standards. Results were expressed as the percentage of the total area.

Data were analyzed using the Generalized Linear Model (GLM) procedure with SAS (Version 9.3, SAS Institute Inc., Cary, NC). According to the categories defined in the Quality Standard, a comparison of the minimum squared means by the t-student test $(P<0.05)$ was done. Relationships between the subcutaneous and cover fat deposits were calculated using the Pearson correlation coefficient.

\section{RESULTS AND DISCUSSION}

\subsection{Analysis of the subcutaneous fat deposit. Fatty acid profile}

Tables 3 and 4 show the fatty acid profiles of the subcutaneous and cover fat deposits of the dry-cured shoulders, respectively. As it can be observed in table 3 , results confirm the greater saturation for the cebo and campo categories, and a higher unsaturation of recebo and bellota 
Table 3

Fatty acid composition of the subcutaneous fat in the carcass depending on the four feeding categories defined in the Standard Quality

\begin{tabular}{|c|c|c|c|c|c|c|}
\hline & \multicolumn{4}{|c|}{ Feeding type } & \multirow{2}{*}{ VC } & \multirow{2}{*}{ Root MSE } \\
\hline & Bellota & Recebo & Campo & Cebo & & \\
\hline C12:0 & $0.065^{c}$ & $0.066^{c}$ & $0.071^{b}$ & $0.075^{a}$ & 11.80 & 0.008 \\
\hline C14:0 & $1.283^{c}$ & $1.323^{b}$ & $1.424^{\mathrm{a}}$ & $1.455^{\mathrm{a}}$ & 11.04 & 0.149 \\
\hline $\mathrm{C} 16: 0$ & $19.94^{d}$ & $20.56^{c}$ & $21.98^{b}$ & $23.90^{\mathrm{a}}$ & 5.83 & 1.241 \\
\hline C16:1 & $2.156^{c}$ & $2.347^{b}$ & $2.323^{b}$ & $2.639^{a}$ & 18.73 & 0.431 \\
\hline C17:0 & $0.281^{d}$ & $0.317^{c}$ & $0.354^{\mathrm{a}}$ & $0.338^{b}$ & 16.77 & 0.054 \\
\hline C17:1 & $0.294^{c}$ & $0.338^{\mathrm{b}}$ & $0.359^{a}$ & $0.370^{\mathrm{a}}$ & 18.07 & 0.061 \\
\hline C18:0 & $8.87^{d}$ & $9.54^{c}$ & $10.94^{b}$ & $12.00^{\mathrm{a}}$ & 11.18 & 1.138 \\
\hline C18:1 & $55.30^{\mathrm{a}}$ & $53.20^{b}$ & $51.12^{c}$ & $49.00^{d}$ & 4.19 & 2.209 \\
\hline C18:2 & $9.31^{\mathrm{b}}$ & $9.85^{\mathrm{a}}$ & $9.01^{c}$ & $8.08^{d}$ & 11.89 & 1.072 \\
\hline C18:3 & $0.781^{b}$ & $0.853^{\mathrm{a}}$ & $0.810^{b}$ & $0.588^{c}$ & 23.95 & 0.184 \\
\hline $\mathrm{C} 20: 0$ & $0.173^{c}$ & $0.177^{\circ}$ & $0.194^{b}$ & $0.202^{\mathrm{a}}$ & 13.99 & 0.026 \\
\hline C20:1 & $1.555^{\mathrm{a}}$ & $1.438^{\mathrm{b}}$ & $1.420^{b}$ & $1.368^{\mathrm{c}}$ & 14.36 & 0.212 \\
\hline SFA & $30.61^{d}$ & $31.98^{c}$ & $34.96^{b}$ & $37.96^{a}$ & 6.45 & 2.153 \\
\hline MUFA & $59.30^{\mathrm{a}}$ & $57.32^{b}$ & $55.22^{c}$ & $53.37^{d}$ & 3.91 & 2.222 \\
\hline PUFA & $10.09^{b}$ & $10.70^{\mathrm{a}}$ & $9.82^{c}$ & $8.66^{d}$ & 12.09 & 1.182 \\
\hline ISFA & $69.39^{a}$ & $68.02^{b}$ & $65.04^{c}$ & $62.04^{d}$ & 3.23 & 2.153 \\
\hline
\end{tabular}

${ }^{a-d}$ Values in the same row without a common superscript letter are significantly different $(P<0.05)$. Data are shown as Average Minimum Quadratic. VC: Coefficient of Variation, and Root MSE: Root of the Mean Square Error of the model.

SFA: Saturated Fatty Acids; MUFA: Monounsaturated Fatty Acids; PUFA: Polyunsaturated Fatty Acids; ISFA: Intermediate-chain Saturated Fatty Acids.

categories. Previous studies have confirmed a higher level of subcutaneous fat fatty acids of pigs fed with feed concentrates and a higher level of mono- and poliunsaturated fatty acids in pigs fed with acorns (Ruíz et al., 1998; Pérez-Palacios et al., 2009). An interesting result is that lower percentages of MUFA (palmitoleic and margaroleic acids) were found in bellota pigs, although it did not happen with the gadoleic acid, which was higher in bellota. A greater poliunsaturation of the recebo vs. bellota (linoleic and linolelic acids) was also found.

In relation to the cover fat fatty acid profile of the dry-cured shoulders (Table 4), the same lipid pattern as the subcutaneous fat has been maintained according to the feeding type, although with a higher variability among samples with the exception of the araquidonic acid (C20:0). Petrón et al. (2004) also found a higher content of saturated fatty acids in hams from pigs fed with feed concentrate, and a greater content of MUFA and PUFA in pigs fed according to the montanera regime.

Table 5 shows the correlation between the fatty acid contents of the subcutaneous fat samples from 99 pigs with traceability and the correspondent cover fat samples. Correlations are statistically significant $(\mathrm{P}<0.001)$ without taking into account the feeding type, with values greater than 0.60 and the exception of margaric acid (0.48). However, results are very different using the different feeding types, due to the fact that correlations are very high in the cebo category (around 90\%, except for PUFA), probably because samples are from the same batch, and clearly lower in recebo and bellota categories. For instance, in the bellota type, correlations in the four main fatty acids are: 0.42 , $0.46,0.53$ and 0.18 for palmitic, estearic, oleic, and linoleic acids respectively, without statistical signification for the first and last fatty acids and with differences $(P<0.05)$ for the rest. So, for extensive systems, the fatty acid profile obtained for the subcutaneous fat was not an indication of a drycured sample.

After finding such different results for each feeding type, with very high values in the cebo category, the correlations among each batch were calculated (García-Casco et al., 2013). These results are shown in Table 6 , in which values obtained for the three types of extensive feedings were again quite variable, although they did not reach the values obtained for the cebo batches. So a higher correspondence is confirmed between both fatty acid profiles (subcutaneous and drycured fats) in pigs sacrificed at a young age and feeding in the most controlled way. 
Table 4

Fatty acid composition of the cover fat in the dry-cured shoulders depending on the four feeding categories defined in the Standard Quality

\begin{tabular}{|c|c|c|c|c|c|c|}
\hline & \multicolumn{4}{|c|}{ Feeding type } & \multirow{2}{*}{ VC } & \multirow{2}{*}{ Root MSE } \\
\hline & Bellota & Recebo & Campo & Cebo & & \\
\hline C12:0 & $0.060^{b}$ & $0.071^{a}$ & $0.073^{a}$ & $0.073^{a}$ & 14.59 & 0.0084 \\
\hline C14:0 & $1.196^{b}$ & $1.372^{\mathrm{a}}$ & $1.432^{\mathrm{a}}$ & $1.375^{\mathrm{a}}$ & 13.74 & 0.1605 \\
\hline C16:0 & $21.14^{d}$ & $22.64^{\mathrm{C}}$ & $24.25^{b}$ & $25.33^{a}$ & 8.80 & 1.4032 \\
\hline C16:1 & $2.32^{b}$ & $2.68^{a}$ & $2.70^{\mathrm{a}}$ & $2.72^{\mathrm{a}}$ & 21.07 & 0.5259 \\
\hline C17:0 & $0.278^{\mathrm{b}}$ & $0.312^{\mathrm{ab}}$ & $0.346^{a}$ & $0.360^{\mathrm{a}}$ & 34.17 & 0.1069 \\
\hline C17:1 & $0.276^{b}$ & $0.297^{b}$ & $0.310^{b}$ & $0.374^{a}$ & 24.75 & 0.0706 \\
\hline C18:0 & $9.63^{c}$ & $10.12^{c}$ & $11.73^{b}$ & $12.84^{\mathrm{a}}$ & 15.07 & 1.1967 \\
\hline C18:1 & $55.19^{\mathrm{a}}$ & $52.29^{b}$ & $50.08^{c}$ & $48.39^{c}$ & 6.89 & 2.6338 \\
\hline C18:2 & $7.97^{\mathrm{a}}$ & $8.30^{\mathrm{a}}$ & $7.19^{b}$ & $6.80^{\mathrm{b}}$ & 13.56 & 0.8812 \\
\hline C18:3 & $0.535^{b}$ & $0.682^{\mathrm{a}}$ & $0.649^{a}$ & $0.489^{b}$ & 26.06 & 0.1414 \\
\hline $\mathrm{C} 20: 0$ & $0.171^{b}$ & $0.170^{\mathrm{b}}$ & $0.179^{a b}$ & $0.189^{a}$ & 11.11 & 0.0187 \\
\hline C20:1 & $1.234^{\mathrm{a}}$ & $1.068^{\mathrm{b}}$ & $1.063^{b}$ & $1.052^{b}$ & 16.44 & 0.1673 \\
\hline SFA & $32.48^{d}$ & $34.68^{c}$ & $38.01^{b}$ & $40.17^{\mathrm{a}}$ & 10.01 & 2.3577 \\
\hline MUFA & $59.02^{a}$ & $56.34^{\mathrm{b}}$ & $54.15^{c}$ & $52.54^{\mathrm{C}}$ & 6.11 & 2.5195 \\
\hline PUFA & $8.50^{\mathrm{a}}$ & $8.98^{\mathrm{a}}$ & $7.83^{b}$ & $7.29^{b}$ & 13.83 & 0.9890 \\
\hline ISFA & $67.52^{\mathrm{a}}$ & $65.32^{b}$ & $61.99^{c}$ & $59.83^{d}$ & 5.67 & 2.3578 \\
\hline
\end{tabular}

${ }^{a-d}$ Values in the same row without a common superscript letter are significantly different $(P<0.05)$. Data are shown as average minimum quadratic. VC: Coefficient of Variation, and Root MSE: Root of the Mean Square Error of the model.

SFA: Saturated Fatty Acids; MUFA: Monounsaturated Fatty Acids; PUFA: Polyunsaturated Fatty Acids; ISFA: Intermediate-chain Saturated Fatty Acids.

\subsection{Prediction of the feeding type according to the fatty acid profile}

Tables 8,9 and 10 show the results from the feeding type prediction in the finish-fattening period according to the fatty acid analysis, the main objective of this project. To reach this prediction the established limit by $\mathrm{ASICI}$ and the Ministery for the categories of recebo and bellota in the Order APA/3653/2007 of the $13^{\text {th }}$ of December (BOE number 300 from $15^{\text {th }}$ of December) was applied and results are shown in table 7.

Until 2007, the MAPA approved each year the percentages of the main four fatty acids analyzed by gas chromatography of the subcutaneous fat samples, to classify each specific batch into one of the old commercial categories (bellota recebo or pienso). However, between 2004 and 2007 the approved limits did not change, but according to the interlaboratory analysis developed by the INTAEX meat department in collaboration with $\mathrm{ASICI}$ since 2001, a high variability for the values of these four main fatty acids exists among periods.

As can be observed in Table 8, the success for $2008 / 09$ samples was $81 \%$, with only 40 failures out of 208 in the allocation of feeding category. It is important to highlight that most of errors were made in three batches: from the campo of fattening cebo from Olivenza, recebo with poor acorns from Valdesequera, and Pedroche's recebo. In the samples from Olivenza 12 mistakes of a total of 13 samples ( $8 \%$ success) were produced, in which 9 samples were included in the bellota category according to the Order APA/3653 (B.O.E. 300 , (2007)), although the medium percentage of linoleic acid was quite low $(7.56 \%)$ in comparison with the bellota batches from Cabeza la Vaca or Ciudad Rodrigo (9.15\% and $9.39 \%$, respectively). Other authors have found linoleic acid percentages similar to these in subcutaneous fat from pigs fed with grass and acorns (Pérez-Palacios et al., 2009). So a revision of the linoleic acid should avoid these mistakes. In the samples from Valdesequera with poor acorns, included in the recebo category, the percentage of oleic acid was very low $(49.6 \%)$ so most of them were classified as Cebo/campo, with a percentage of success of only $8 \%$. The production of acorns depends on multiple factors (climate, specie productive cycles, management, etc.) and its nutritive characterization is of great importance to the body weight gain of the animals, which is reflected in the composition of the animal's adipose tissue (Isabel and González, 2008). Pigs from this batch had lower reposition levels than what the Quality Standard establishes with a montanera duration in the limit cited in the 
Table 5

Values of the total correlation and the correlations depending on the feeding type of the fatty acid content between the subcutaneous and cover fats from the dry-cured shoulders

\begin{tabular}{|c|c|c|c|c|c|c|c|}
\hline & \multirow{2}{*}{ All } & \multicolumn{4}{|c|}{ Feeding Type } & \multicolumn{2}{|c|}{ VC } \\
\hline & & Bellota & Recebo & Campo & Cebo & Subcutaneous fat & Dry-cured shoulder \\
\hline C12:0 & $0.718^{* * *}$ & $0.703^{* \star *}$ & $0.646^{* * *}$ & $0.287^{\mathrm{ns}}$ & $0.962^{* * *}$ & 13.87 & 13.49 \\
\hline C14:0 & $0.700^{\star \star \star}$ & $0.601^{\star \star}$ & $0.738^{\star \star \star}$ & $0.276^{\mathrm{ns}}$ & $0.982^{\star \star \star}$ & 12.52 & 12.26 \\
\hline C16:0 & $0.773^{* \star \star}$ & $0.420^{\text {ns }}$ & $0.688^{\star \star \star}$ & $0.442^{\star \star \star}$ & $0.940^{\star \star \star}$ & 8.23 & 8.26 \\
\hline C16:1 & $0.625^{\star \star \star}$ & $0.169^{\text {ns }}$ & $0.803^{\star \star \star}$ & $0.597^{\star \star \star}$ & $0.975^{\star \star \star}$ & 17.87 & 17.77 \\
\hline $\mathrm{C} 17: 0$ & $0.482^{\star \star \star}$ & $0.435^{\mathrm{ns}}$ & $0.470^{\star \star}$ & $0.294^{\mathrm{ns}}$ & $0.938^{\star \star \star}$ & 18.90 & 37.71 \\
\hline C17:1 & $0.621^{\star \star \star}$ & $0.060^{\mathrm{ns}}$ & $0.588^{\star \star \star}$ & $0.659^{\star \star \star}$ & $0.975^{\star \star \star}$ & 19.94 & 21.39 \\
\hline C18:0 & $0.850^{\star \star \star}$ & $0.463^{*}$ & $0.766^{\star \star \star}$ & $0.784^{\star \star \star}$ & $0.831^{* \star *}$ & 16.21 & 15.53 \\
\hline C18:1 & $0.800^{* * *}$ & $0.531^{*}$ & $0.743^{* * *}$ & $0.638^{* * *}$ & $0.903^{* * *}$ & 6.16 & 6.66 \\
\hline C18:2 & $0.746^{* * *}$ & $0.178^{\text {ns }}$ & $0.337^{\mathrm{ns}}$ & $0.744^{* * *}$ & $0.730^{*}$ & 11.06 & 12.89 \\
\hline C18:3 & $0.697^{* * *}$ & $0.518^{*}$ & $0.655^{* * *}$ & $0.504^{* * *}$ & $0.667^{*}$ & 20.70 & 27.50 \\
\hline $\mathrm{C} 20: 0$ & $0.668^{\star \star \star}$ & $0.403^{\mathrm{ns}}$ & $0.567^{\star \star \star}$ & $0.649^{\star \star \star}$ & $0.864^{\star \star \star}$ & 12.89 & 9.82 \\
\hline $\mathrm{C} 20: 1$ & $0.718^{* * *}$ & $0.570^{* *}$ & $0.695^{\star \star *}$ & $0.758^{* * * *}$ & $0.984^{* * *}$ & 15.50 & 16.35 \\
\hline SFA & $0.840^{\star \star \star}$ & $0.540^{\star}$ & $0.738^{* \star \star}$ & $0.675^{\star \star \star}$ & $0.881^{\star \star \star}$ & 10.00 & 9.92 \\
\hline MUFA & $0.813^{\star \star \star}$ & $0.584^{\star \star}$ & $0.730^{\star \star \star}$ & $0.697^{\star \star \star}$ & $0.899^{\star \star \star}$ & 5.63 & 6.03 \\
\hline PUFA & $0.748^{\star \star \star}$ & $0.250^{\mathrm{ns}}$ & $0.327^{\mathrm{ns}}$ & $0.739^{\star \star \star}$ & $0.731^{*}$ & 11.31 & 13.35 \\
\hline ISFA & $0.840^{* * *}$ & $0.540^{*}$ & $0.737^{* \star *}$ & $0.675^{* * *}$ & $0.881^{* * *}$ & 5.21 & 5.64 \\
\hline
\end{tabular}

Significance level: ns=no significance, ${ }^{*}=P<0.05 ;{ }^{* *}=P<0.01 ;{ }^{* * *} P<0.001$

VC: Coefficient of Variation. SFA: Saturated Fatty Acids; MUFA: Monounsaturated Fatty Acids; PUFA: Polyunsaturated Fatty Acids; ISFA: Intermediate-chain Saturated Fatty Acids.

Table 6

Statistical values of the correlation between the content of major fatty acids of subcutaneous and cover fat from dry-cured shoulders depending on batch origin

\begin{tabular}{|c|c|c|c|c|c|}
\hline Type & Batch and Period & C16:0 & C18:0 & C18:1 & C18:2 \\
\hline \multirow[t]{2}{*}{ Bellota } & Ciudad Rodrigo 08/09 & $0.766^{* *}$ & $0.314^{\mathrm{ns}}$ & $0.811^{* * *}$ & $0.080^{\text {ns }}$ \\
\hline & Valdesequera 09/10 & $-0.046^{\text {ns }}$ & $0.416^{\mathrm{ns}}$ & $-0.129^{\text {ns }}$ & $-0.191^{\mathrm{ns}}$ \\
\hline \multirow[t]{3}{*}{ Recebo } & Bellota pobre Valdesequera 08/09 & $0.256^{\text {ns }}$ & $0.888^{* * *}$ & $0.569^{\text {ns }}$ & $-0.023^{\text {ns }}$ \\
\hline & Postre Valdesequera 09/10 & $0.525^{\mathrm{ns}}$ & $0.716^{*}$ & $0.667^{\star}$ & $0.434^{\text {ns }}$ \\
\hline & Norma Valdesequera 09/10 & $0.615^{\mathrm{ns}}$ & $0.726^{*}$ & $0.746^{\star}$ & $0.303^{\text {ns }}$ \\
\hline \multirow[t]{4}{*}{ Campo } & Recebo pobre Valdesequera 08/09 & $0.573^{\text {ns }}$ & $0.752^{*}$ & $0.653^{*}$ & $0.230^{\text {ns }}$ \\
\hline & Valdesequera engrasado 09/10 & $0.437^{\text {ns }}$ & $0.661^{*}$ & $0.570^{\mathrm{ns}}$ & $0.128^{\text {ns }}$ \\
\hline & Valdesequera no engrasado 09/10 & $-0.036^{\text {ns }}$ & $0.801^{* \star}$ & $-0.274^{\mathrm{ns}}$ & $0.926^{* *+}$ \\
\hline & Valdesequera no engrasado 08/09 & $0.384^{\mathrm{ns}}$ & $0.695^{*}$ & $0.623^{\text {ns }}$ & $0.226^{\text {ns }}$ \\
\hline Cebo & Fuente Obejuna 08/09 & $0.940^{* * *}$ & $0.831^{* \star *}$ & $0.903^{* * *}$ & $0.730^{*}$ \\
\hline
\end{tabular}

Significance level: ns=no significance,${ }^{*}=P<0.05 ;{ }^{* *}=P<0.01 ;{ }^{* * \star} P<0.001$

Quality Standard. So this would explain the high percentage of mistakes obtained in our analysis. For the Pedroches recebo samples, the success was $57 \%$ with a huge heterogeneity in the fatty acid profiles which was translated to a classification of the samples into three categories. However, if an random analysis were made of the whole batch, it would be included in the recebo category (means of $19.44 \%, 8.58 \%, 54.44 \%$ and $11.01 \%$ for palmitic, estearic, oleic, and linoleic, respectively).

Table 9 contains the results obtained in the period 2009/10, in which the global percentage of success was $59 \%$, quite lower than in the previous period. Most of the errors occurred in the batches of fattening campo from Valdesequera and Olivenza, Norma type recebo and Postre of Valdesequera 
Table 7

Analytical values from the 2007-2008 periods to the assignation of bellota and recebo types (MAPA, 2007)

\begin{tabular}{lcccc}
\hline & C16:0 \% & C18:0 \% & C18:1\% & C18:2 \% \\
\hline Bellota & $\leq 22,0$ & $\leq 10,5$ & $\geq 53,0$ & $\leq 10,5$ \\
Recebo & $\leq 24,0$ & $\leq 11,5$ & $\geq 51,0$ & $\leq 11,5$ \\
\hline
\end{tabular}

and bellota of Valdesequera. Many of the errors in the samples of pig fat from campo fed with fattening feed concentrates was due to its classification as recebo and some as bellota, with a very low percentage of linoleic acid as in the previous period $(8.13 \%$ and $8.44 \%$, respectively) versus bellota batches $(9.29 \%$ and $9.98 \%$ from Obejuna and Valdesequera) or recebo (10.02\% and $9.85 \%$ for Norma type of Valdesequera and Postre de Valdesequera). These results would again call for a new review of the Order APA/3653.

For the recebo batch of the Norma type of Valdesequera the same circumstance was produced as in Pedroche recebo of the previous period: a heterogeneity in the fatty acid profiles which triggers a classification into three categories. Although the mean obtained in each one of the main fatty acids of the batch $(20.83 \%, 9.29 \%$, $52.57 \%$ and $10.02 \%$, respectively) classified it into the recebo category. This argument is not valid for the recebo samples type Postre of Valdesequera, in which the pigs' reposition with a daily mixed feeding of acorns and feed concentrates was very elevated (4.85 arroba) and for this reason the fatty acid profile of the batch, with values of $20.79 \%$ for palmitic acid, $9.19 \%$ for stearic acid, $53.50 \%$ for oleic acid and $9.85 \%$ for linoleic acid, corresponded clearly to the bellota category. These results show that it is very difficult to identify montanera management using this method.

The fatty acid profile of the bellota animals from Valdesequera is consistent with the mean batch replacement, slightly lower than the mean replacement established in the Quality Standard (3.58 arroba), placing 12 of the animals as recebo. The oleic acid mean value is $53.19 \%$, very close to the lower limit of this category, so various animals showed lower percentages and they were classified as recebo, although the batch as a set should be classified as bellota.

Finally, the 2010/11 results are shown in Table 10 , with a success of $68 \%$. Although the normal cebo batches (Fuente Obejuna, Salvaleón) were easily predicted, there were mistakes in the cebo batches with fattening feed concentrates. In the case of Topas batches, in which pigs were fattened in a grassy fence and with feed concentrates formulated to get a fatty acid profiles with a high concentration of oleic acid, samples presented a very low percentage of linolenic acid (6.78\%), while the stearic acid percentage was found within the limit (11.47\%). Regarding the Valdesequera batches fed with fattening feed concentrates with a very low number of observations, it was difficult to

Table 8

Classification results obtained from fatty acid analysis of samples from 2008/09, depending on pig batch (García-Casco et al., 2013) and feeding type

\begin{tabular}{|c|c|c|c|c|c|}
\hline \multirow{2}{*}{\multicolumn{2}{|c|}{ Feeding/Batch }} & \multicolumn{3}{|c|}{ Prediction } & \multirow{3}{*}{$\begin{array}{c}\text { Success } \% \\
100\end{array}$} \\
\hline & & \multirow{2}{*}{$\frac{\text { Cebo/Campo }}{32}$} & \multirow[t]{2}{*}{ Recebo } & \multirow[t]{2}{*}{ Bellota } & \\
\hline Cebo & Fuente Obejuna & & & & \\
\hline \multirow[t]{3}{*}{ Campo } & Valdesequera & 22 & 1 & & 96 \\
\hline & Olivenza engrasado & 1 & 3 & 9 & 8 \\
\hline & Recebo pobre Vald & 38 & 1 & & 97 \\
\hline \multirow[t]{2}{*}{ Recebo } & Pedroches & 7 & 16 & 5 & 57 \\
\hline & Bellota pobre Vald & 11 & 1 & & 8 \\
\hline \multirow[t]{2}{*}{ Bellota } & Cabeza la Vaca & & & 29 & 100 \\
\hline & Ciudad Rodrigo & & 3 & 29 & 91 \\
\hline \multicolumn{2}{|l|}{ Total Prediction } & 111 & 25 & 72 & 81 \\
\hline \multicolumn{2}{|c|}{ Total feeding type } & 107 & 40 & 61 & \\
\hline Feeding Type & Cebo/Campo & Recebo & Bellota & Total & Success $\%$ \\
\hline Cebo/Campo & 93 & 5 & 9 & 107 & 87 \\
\hline Recebo & 18 & 17 & 5 & 40 & 43 \\
\hline Bellota & 0 & 3 & 58 & 61 & 95 \\
\hline Total & 111 & 25 & 72 & 208 & 81 \\
\hline
\end{tabular}


Table 9

Classification results obtained from fatty acid analysis of samples from 2009/10, depending on pig batch (García-Casco et al., 2013) and feeding type

\begin{tabular}{|c|c|c|c|c|c|}
\hline \multirow{2}{*}{\multicolumn{2}{|c|}{ Feeding/Batch }} & \multicolumn{3}{|c|}{ Prediction } & \multirow{3}{*}{$\begin{array}{c}\text { Success } \% \\
100\end{array}$} \\
\hline & & \multirow{2}{*}{$\frac{\text { Cebo/Campo }}{25}$} & \multirow[t]{2}{*}{ Recebo } & \multirow[t]{2}{*}{ Bellota } & \\
\hline Cebo & Alburquerque & & & & \\
\hline \multirow[t]{3}{*}{ Campo } & Vald no engrasado & 22 & 3 & & 88 \\
\hline & Vald engrasado & 2 & 13 & 10 & 8 \\
\hline & Olivenza engrasado & 5 & 7 & 13 & 20 \\
\hline \multirow[t]{2}{*}{ Recebo } & Norma Vald & 1 & 16 & 7 & 67 \\
\hline & Postre Vald & & 9 & 16 & 36 \\
\hline \multirow[t]{2}{*}{ Bellota } & Valdesequera & 2 & 12 & 16 & 53 \\
\hline & Fuente Obejuna & & & 25 & 100 \\
\hline \multicolumn{2}{|l|}{ Total Prediction } & 57 & 60 & 87 & 59 \\
\hline \multicolumn{2}{|c|}{ Total Feeding Type } & 100 & 49 & 55 & \\
\hline Feeding Type & Cebo/Campo & Recebo & Bellota & Total & Success \% \\
\hline Cebo/Campo & 54 & 23 & 23 & 100 & 54 \\
\hline Recebo & 1 & 25 & 23 & 49 & 51 \\
\hline Bellota & 2 & 12 & 41 & 55 & 75 \\
\hline Total & 57 & 60 & 87 & 204 & 59 \\
\hline
\end{tabular}

do a correct classification with the established limits in the Order APA/3653 (B.O.E. 300, 2007). Both groups should be included in the recebo category by doing a whole analysis (means of $52.43 \%$ and $52.26 \%$ for oleic acid).

The mistakes of the campo batches were again due to the fattening of cebo from Olivenza, because samples were attributed to recebo and bellota, although the mean percentage of stearic acid $(11.07 \%)$ of this batch should attribute it to the recebo category. It was observed that the mean value of linoleic acid in the batch $(8.83 \%)$ was higher than values found for the same batch of the two previous periods, and even higher that those obtained for all the batches of bellota Origin Designation, contradicting the results of the 08/09 and $09 / 10$ periods. However, the campo especial of Fuente de Cantos batch was correctly classified due to its high percentage of stearic acid $(12.50 \%)$.

With respect to the recebo batches, a good percentage of success was only obtained for the correspondent Recebo 2 Origin Designation. The linoleic acid of the 8 animals from the Valdesequera batch, which only were 30 days in montanera, was exceptionally high (13.14\%) being classified into the cebo category, while the oleic acid of the other two batches (Recebo 1 Origin Designation and Fuente de Cantos) was higher than $51 \%$ in many animals so they were attributed to the bellota category. These results confirm the difficulty in the differentiation of the recebo and bellota categories when the montanera reposition of the recebo is high.
Lastly, batches corresponding to the bellota category were all correctly classified, except for the Valdesequera batch with a 60-day montanera. As in the Valdesequera batch with 30 days of montanera, the problem was found with the linoleic acid percentage, which was very high in some animals. Finally, the other two batches from Valdesequera, with lower success percentages $(69 \%$ and $63 \%$, respectively), show fatty acid mean values for the animal sets that established them in the bellota category.

The fatty acid determination from subcutaneous fat using the analytical technique of gas chromatography has difficulties mainly in differentiating the recebo category, but a revision of the established limits of the Order APA/3653 (B.O.E. 300, 2007) would lead to a solution to many mistakes associated with the use of fattening feed concentrates. A proper preparation of the animals to start the montanera and a higher reposition during the montanera than that established in the Quality Standard would result in fatty acid profiles very similar to those of pure bellota. On the contrary, inadequate feedings in pre-montanera or low repositions in pure bellota would lead to profiles near the campo or even cebo categories.

However, the fatty acid profile method has a great percentage of success when classifying animals into cebo and bellota categories, although Espinosa et al., (2003) concluded that the specificity of the technique is not so desirable due to a high percentage of false negatives found in the comparative study. These errors could be solved by 
Table 10

Classification results obtained from fatty acid analysis of samples from 2010/11, depending on pig batch (García-Casco et al., 2013) and feeding type

\begin{tabular}{|c|c|c|c|c|c|}
\hline \multirow{2}{*}{\multicolumn{2}{|c|}{ Feeding/Batch }} & \multicolumn{3}{|c|}{ Prediction } & \multirow{3}{*}{$\begin{array}{c}\text { Success \% } \\
95\end{array}$} \\
\hline & & \multirow{2}{*}{$\begin{array}{c}\text { Cebo/Campo } \\
21\end{array}$} & \multirow[t]{2}{*}{ Recebo } & \multirow{2}{*}{$\frac{\text { Bellota }}{1}$} & \\
\hline Cebo & Fuente Obejuna & & & & \\
\hline & Salvaleón & 14 & 1 & & 93 \\
\hline & CB1 Proyecto Vald. & 3 & 4 & 1 & 38 \\
\hline & CB2 Proyecto Vald. & 2 & 5 & 3 & 20 \\
\hline & Pienso Especial Topas & 14 & 6 & 5 & 56 \\
\hline \multirow[t]{2}{*}{ Campo } & Olivenza engrasado & 7 & 10 & 5 & 32 \\
\hline & Esp. F. de Cantos & 23 & & 2 & 92 \\
\hline \multirow[t]{4}{*}{ Recebo } & Vald. 30 Días & 8 & & & 0 \\
\hline & DO Recebo 1 & & 4 & 15 & 21 \\
\hline & DO Recebo 2 & 4 & 10 & 1 & 67 \\
\hline & Fuente de Cantos & 3 & 6 & 11 & 30 \\
\hline \multirow[t]{10}{*}{ Bellota } & Vald. 60 Días & & 6 & 2 & 25 \\
\hline & Vald. 90 Días & & & 8 & 100 \\
\hline & Vald. Montanera 1 & 1 & 3 & 9 & 69 \\
\hline & Vald. Montanera 2 & & 6 & 10 & 63 \\
\hline & DO Bellota 1 & & & 15 & 100 \\
\hline & DO Bellota 2 & & & 15 & 100 \\
\hline & DO Bellota 3 & & 1 & 14 & 93 \\
\hline & DO Bellota 4 & & & 15 & 100 \\
\hline & DO Bellota 5 & & 1 & 14 & 93 \\
\hline & DO Bellota 6 & & & 15 & 100 \\
\hline \multicolumn{2}{|l|}{ Total Prediction } & 100 & 63 & 161 & 68 \\
\hline \multicolumn{2}{|c|}{ Total Feeding Type } & 127 & 62 & 135 & \\
\hline Feeding Type & Cebo/Campo & Recebo & Bellota & Total & Success $\%$ \\
\hline Cebo/Campo & 84 & 26 & 17 & 127 & 66 \\
\hline Recebo & 15 & 20 & 27 & 62 & 32 \\
\hline Bellota & 1 & 17 & 117 & 135 & 87 \\
\hline Total & 100 & 63 & 161 & 324 & 68 \\
\hline
\end{tabular}

taking into account the more real values for the four main fatty acids for classification into commercial categories, setting new limits according to each origin Designation background and considering geographical and climate differences. According to Vázquez et al. (2000) climate, species production, management, genetic variety and plagues activity have a great influence on acorn quality. Tejerina et al. (2011) confirmed that acorn and grass fatty acid profiles vary depending on the sampled date in the same period of montanera and year of study, especially in the saturated fatty acids and the C18:1 (oleic acid) content, due to the fact that the composition of acorns varies according to ripeness. At the same time, the grass production during montanera highly depends on autumn climate conditions, mainly on rainfall and frost frequency, finding great climate differences among locations (Espárrago et al., 1999). As mentioned previously, the lipid composition of pigs depends on the fat eaten by the animals; because of the fact that monogastric animals incorporate fatty acids from their diet with low modifications (Decker et al., 2010).

For this reason, most of the errors associated with the method are due to the reference values used which are based on previous periods that are not totally valid, resulting in a high variability for the montanera period each year (Tejerina et al., 2011), so the help of fieldwork is necessary. 


\section{CONCLUSIONS}

The results of the present studies show that the determination of the fatty acid profile using gas chromatography is not a consistent method to classify the animals according to their diet in the recebo category, although it provides good percentages of success to classify animals into bellota and cebo categories. These percentages could be improved if the quantification limits were adequate, elaborated with information from previous periods, discriminating among geographical locations. So this method could continue to be used as a verification method, without forgetting field inspections and complementing it with some of the alternative methods developed over recent years.

\section{ACKNOWLEDGEMENT}

This study has been financed by the project RTA2008-0026 of the Instituto Nacional de Investigación y Tecnología Agraria y Alimentaria (INIA). The authors thank Olivia Fariña for her excellent lab work.

\section{REFERENCES}

B.O.E. 247, (15/10/2001), 37830-37833. Real Decreto $1083 / 2001$ de 5 de octubre, por el que se aprueba la norma de calidad para el jamón ibérico, paleta ibérica y caña de lomo ibérico elaborados en España.

B.O.E. 211, (01/09/2004), 30328-30329. Real Decreto $1781 / 2004$, de 30 de julio, por el que se modifica el Real Decreto 1083/2001, de 5 de octubre, por el que se aprueba la norma de calidad para el jamón ibérico, paleta ibérica y caña de lomo ibérico elaborados en España.

B.O.E. $283(24 / 11 / 2004), \quad 38770-38779 . \quad$ ORDEN PRE/3844/2004, de 18 de noviembre, por la que se establecen los métodos oficiales de toma de muestras en canales de cerdos ibéricos y el método de análisis para la determinación de la composición de ácidos grasos de los lípidos totales del tejido adiposo subcutáneo de cerdos ibéricos.

B.O.E. 264, (03/11/2007), 45087-45104. Real Decreto 1469/2007, de 2 de noviembre, por el que se aprueba la norma de calidad para la carne, el jamón, la paleta y la caña de lomo ibéricos.

B.O.E. 300 (15/12/2007), 51655-51655. ORDEN APA/3653/2007, de 13 de diciembre, por la que se publican los valores de ácidos grasos aplicables a las designaciones de alimentación «Bellota» y «Recebo», para la campaña 2007-2008.

Decker E, Park Y. 2010. Healthier meat products as functional foods. Meat Science 89, 49-55.
Espárrago Carande F, Cabeza de Vaca Munilla F, Cervini Gagliardi L. 1999. Alimentación y sistemas de explotación del cerdo Ibérico en cebo y calidad de las producciones. Sólo Cerdo Ibérico 3, 51-66.

Espinosa J, Barandarian M, Cava R, Fariña O, Alonso A, Sanabria C. 2003. Estudio comparativo de la clasificación en montanera en la campaña 02-03 mediante el perfil de ácidos grasos de la grasa subcutánea y por los datos obtenidos por el control de los servicios técnicos del C.R.D.O. Dehesa de Extremadura. II Congreso Mundial del Jamón sobre Ciencia, Tecnología y Comercialización, Cáceres, 26-28 de marzo.

García-Olmo J, De Pedro E, Garrido A, Paredes A, Sanabria C, Santolalla M, Salas J, García-Hierro JR, González I, García-Cachán MD, Guirao J. 2002. Determination of the precision of the fatty acid analysis of Iberian pig fat by gas chromatography. Results of a mini collaborative study. Meat Sci. 60, 103-109.

García-Casco J, Muñoz M, González E. 2013. Predictive ability of feeding system by several analytical methods in iberian pig. Grasas Aceites. 64, 191-200.

Isabel B, González JL. 2008. Valoración nutritiva de la bellota en la montanera 2007-2008. Repercusiones en la gestión de la dehesa AECERIBER (Ed.). Sólo Cerdo Ibérico, tomo I, Zafra 352-357.

Pérez-Palacios T, Ruiz J, Tejeda JF, Antequera T. 2009. Subcutaneous and intramuscular lipid traits as tools for classifying lberian pigs as a function of their feeding background. Meat Sci. 81, 632-640.

Petrón MJ, Muriel E, Timón ML, Martín L, Antequera T. 2004. Fatty acids and triacylglycerols profiles from different types of Iberian dry-cured hams. Meat Sci. 68, 71-77.

Ruiz J, Cava R, Antequera T, Martin L, Ventana J, López-Bote, C. 1998. Prediction of the Feeding Background of Iberian Pigs Using the Fatty Acid Profile of Subcutaneous, Muscle and Hepatic Fat. Meat Sci. 49, 155-163.

Tejerina D, García-Torres S, Cabeza de Vaca M, Vázquez FM, Cava R. 2011. Acorns (Quercus rotundifolia Lam.) and grass as natural sources of antioxidants and fatty acids in the "montanera" feeding of Iberian pig: Intra- and inter-annual variations. Food Chem. 124, 997-1004.

UNE-EN ISO 5508:1996. Aceites y grasas de origen animal y vegetal. Análisis por cromatografía en fase gaseosa de los ésteres metílicos de ácidos grasos. (ISO 5508:1990). AENOR.

Vázquez-Pardo FM, Doncel-Pérez E, Ramos-Maqueda S. 2000.Valoración de montaneras: Producción frutal y evolución de la calidad. II Jornadas El Cerdo Ibérico y sus Productos. Salamanca 24 y 25 de mayo de 2000.

Recibido: $16 / 10 / 12$ Aceptado: 26/1/13 